\title{
Study of a Four-armed Gilt Bronze Standing Bodhisattva Unearthed in Jambi, South Sumatra
}

\author{
ITŌ Naoko
}

\section{Introduction}

The four-armed gilt bronze standing bodhisattva statue (no. 04.094), which belongs to the Museum Negeri Propinsi Jambi, is considered to be an important work representing the Śrivijaya style. However, prior research on the piece is very limited. Thus, I would like to present a thorough analysis of its forms in this paper. The statue was discovered on February 3,1991, by a farmer in the district of Rantaukapastuo in the village of Muara Tembesi in Batanghari, State of Jambi, South Sumatra, Indonesia, together with a four-armed gilt bronze standing Avalokiteśvara statue (no. 04.093). ${ }^{1)}$

\section{General Features}

The statue measures $29.0 \mathrm{~cm}$ high, with a maximum breadth of $12.8 \mathrm{~cm}$ (from the left to the right elbow), and has a gilt finish. The piece has been damaged all over and shows signs of greenish corrosion where it has been damaged. Of the four hands, the first and second right hands, as well as the first left hand remain intact. The second left hand from the wrist up, and the part from the skirt downward, including both feet, are missing. The back side is damaged allover, and the fingertips and the right ear lobe are also missing. The upper body leans forward, and the lower body is also slightly warped forward. Such status suggests that some pressure was applied from around the back of the head, which damaged the entire back side, and that the corrosion progressed thenceforth.

Regarding the body figure, the right hip is tilted, giving the body a subtle reverse Sshaped line. Large cracks run down the elbows of the two right hands and down the 
（280） Study of a Four-armed Gilt Bronze Standing Bodhisattva Unearthed in Jambi, South Sumatra（ITō）

thighs. The front of the figure is almost flat with no modulation and fairly static. The statue has broad shoulders and a slender waist that twists to the right, bearing the main weight of the body on the right foot. Even upon taking into consideration the length of the missing parts, one can see that the head is large in proportion to the body. Features such as the hair done up high in a bun, the large ürnā on the forehead, and the relatively simple adornment-bearing only a few decorations such as waistbands and armlets - that contrasts with the careful workmanship of the face, can be seen as the statue's distinctive features.

\section{Specific Features}

The distance from the top of the head to the chin is $7.5 \mathrm{~cm}$. The hair is done up in a conical bun that is $2.2 \mathrm{~cm}$ high. The distance between the hairline and chin is $2.7 \mathrm{~cm}$. The distance between the ears, including the pinnae, is $4.0 \mathrm{~cm}$ and the distance from the tip of the nose to the back of the head is $3.8 \mathrm{~cm}$. A small empty niche is crafted in the front of the bun. U-shaped coils of hair hang down from on both sides of the bun from the top of the head to the shoulders. The statue wears a crown that consists of three upright ornaments decorated with floral patterns. U-shaped locks of hair hang down from the top of the crown to the right and left shoulders. The distance from the front to the back of the bun is shallow, and below the empty niche is a grid-patterned pedestal. The face is slightly egg-shaped and the eyebrows are arched. Both brows are engraved in long lines and are connected in the middle. A large circular ūrnā is decorated along the line. Both corners of the eyes are pointed upwards, and there are contour lines above and below the pupils and engraved lines along the upper lids. The nose is straight, the lips are thick with contour lines on the upper and lower lips, and the corners of the mouth are raised significantly in the shape of a bow. With the exception of the center of the ürnā and the lower left part of the nose, there is almost no damage. The pointed chin is characteristic, and the neck is marked with three lines, with a crack visible on the left part. The chest has circular nipples with lines drawn in a radial pattern around them.

On the back side, the back of the head (which has an oval hole in the middle with the severed piece fitted inside) and from the shoulders down to the tip of the skirt is damaged and missing. The shoulders are damaged all over. As for the four arms, armlets 
are engraved in lines on both arms, and all except for the second left hand from the wrist up is intact. There are horizontal cracks on both right elbows. According to museum documents, the cracks were sustained at the time of the discovery. The first right hand forms the wish-granting gesture (varadamudrā). All of the fingertips are missing. There are two creases in the palm along the hollows of the hand, with a circular shape in the center. Although the little finger of the second hand is missing, the hand grasps a sutra scroll (pustaka). The fingertips of the first left hand are missing except for the little finger, but from the vertical rust trace on the palm, it is likely that the hand was holding the stem of a lotus (padma).

The waist is slender, with no navel, and a narrow strip of cloth is wrapped around it. The lower abdomen bulges slightly. A thin skirt is worn from the waist down, which is gathered together at the center of the left thigh. Lines indicating the folds of the cloth are engraved many-fold diagonally from the upper right. The skirt is light enough to accentuate the shape of the figure's legs. A horizontal crack runs across the thighs. The area below the hem of the skirt is damaged and missing.

\section{Analysis on the Damaged Part of the Bun}

I would now like to make an observation on the damaged front side of the bun. Twentyseven images have been confirmed as having been unearthed in Indonesia. ${ }^{2)}$ All show a transformation buddha at the front of the bun.

There is also an example of a four-armed sitting figure with a transformation buddha on the head, in the Avalokiteśvara scene of Gandavyūhasūtra created on the wall of the Second Gallery at Candi Borobudur in Central Java, built between the 8th and 9th centuries. Furthermore, considering what could be placed in front of the bun, there are examples of Maitreya images with a small tower (stūpa) on the head. At the present, 7 figures can be seen in Indonesia, but all 4 standing and 3 sitting figures are twoarmed. ${ }^{3)}$ Four-armed figures such as the statue we are looking at in this paper cannot be considered as Maitreya images. Thus, there is a high possibility that a transformation buddha had been placed in the cavity in the front of the bun. If one is to consider the transformation buddha as a characteristic of Avalokiteśvara images, one may consider that this is an Avalokiteśvara Statue. ${ }^{4)}$ 


\section{Analysis of the Hand-held Attributes}

Regarding the hand-held attributes of the statue, the first right hand is in the form of the varadamudrā, the second right hand holds a pustaka, the first left hand holds nothing but has traces of a padma stem, and the second left hand is missing.

As an example of four-armed standing Avalokiteśvara statues unearthed in Central Java, I would like to look first at a statue unearthed in Palembang, Sumatra, dated around the 7th-8th centuries (Museum Pusat Nasional, Indonesia). Looking at the attributes of this statue in the aforementioned order, they seem to be: missing, akșamālā, missing, and a pustaka. The attributes of the four-armed standing figure shown in the relief on the wall of Candi Mundut built around the 8th-9th centuries in Central Java, are: missing, akșamālā, padma, and a pustaka. These two statues demonstrate that four-armed standing bodhisattva images were created in Indonesia in the 8th century, with akșamāla in the second right hand, and a pustaka in the second left hand. Looking now at examples of four-armed Avalokiteśvara images in cast metal, twenty-seven images have been confirmed as having been unearthed in Central Java, East Java, West Borneo, Sumatra, and Lombok. ${ }^{5)}$ The pieces are dated around the 7th12 th centuries. Regarding the material, bronze is most common with 20 examples. Four are gilt-bronze, two are made of gold, and one of silver. Except for the silver figure measuring $98.1 \mathrm{~cm}$ high (end of the 8 th to the beginning of the 9th century; unearthed in Central Java, 509 A238; Museum Pusat Nasional, Indonesia), ${ }^{6}$ the statues are all small, ranging from 10.0-28.5 $\mathrm{cm}$. As for the attributes, most common among the statues with all four arms intact is the combination of varadamudrā, akșamālā, padma, and a pustaka. All eleven undamaged four-armed standing Avalokiteśvara shows this combination, and many of the sixteen figures with partially missing attributes also fit in this combination of varadamudrā, akșamālā, padma, and a pustaka. Furthermore, this four-armed sitting Avalokiteśvara image shows the same characteristic. ${ }^{7)}$ The attributes of the sitting Avalokiteśvara image in the Gandavyūhasūtra relief on the wall of the Second Gallery of Candi Borobudur built around the 8th-9th centuries are: varadamudrā, unidentifiable, padma stem (?), and a pustaka (baton-shaped). The attributes of the stone figure in Candi Plasosan in Central Java built around the 9th century are also: varadamudrā, aksamālā, missing, and a pustaka. Based on the fact that there are 20 cast metal figures 
most of which have the same combination of attributes as the standing figures, one may conclude that among the standing and sitting images in Indonesia, the common attributes for the four-armed Avalokiteśvara are: varadamudrā, akșamālā, padma, and a pustaka.

As for examples with combinations of 4 attributes different from the one mentioned above, there is a statue in a private collection with: varadamudrā, akșamālā, missing, and a conch (śamkhah). There is also a figure showing: varadamudrāa, akșamālā, padma, and a śamkhah (no. 1403-2838, Rijksmuseum Volkenkunde), and another with: missing, unidentifiable, missing, and a śamkhah (no. 1403-2440, Rijksmuseum Volkenkunde). Thus, there are 3 examples that hold a sammkhah in the second left hand. There was also an example with: a disc-shaped attribute, akșamālā, water bottle (kamandalu), and pustaka (no. 1403-2384, Rijksmuseum Volkenkunde). In any case, examples with a pustaka in the second right hand, as in the case of the statue in this paper cannot be found. Thus, we may say that this is a very exceptional case. Furthermore, looking at the four-armed standing Avalokiteśvara statues in India, there are a couple of examples from the Pāla dynasty including those found in Nālandā and Gaya that feature varadamudrā, akșamālā, padma, and pustaka. However, in most cases the attributes are: varadamudrā, akșamālā, padma, and kamandalu. ${ }^{8)}$ In any case, examples holding pustaka in the second right hand cannot be seen. However, the attributes of a four-armed standing Avalokiteśvara statue in Bangkok National Museum dated around the 10th century are: padma, akșamālä, kamandalu, and pustaka. Thus, there are also combinations besides those with varadamudrā.

In this section, I have mainly considered the attributes of other four-armed standing and sitting bodhisattvas in Indonesia. The comparison between the attributes of the above examples and this statue, which holds a pustaka in the second right hand, reveals that this statue differs from the other Indonesian examples. Thus, based on the remaining attributes, the varadamudrā, pustaka, and the padma, it is most likely that the attribute of the second left hand was akșamālā.

\section{Artistic Style}

The hair of the statue in this paper hangs down on the shoulders in gently waving warabite 蔽手 style locks. Considering the style of the facial features, although the 
（284） Study of a Four-armed Gilt Bronze Standing Bodhisattva Unearthed in Jambi, South Sumatra（ITŌ)

statue has a sharp chin, it probably fits in the Dvāravati style in the Malay Peninsula, shortly before the Indian Pāla style spread to Sumatra. In South-Sumatra, three wellknown and excellent Buddhist statues have been found. All of them are now in the collection of the National Museum in Jakarta: a thatāgata statue unearthed in the Komering River in Palembang (40.0 cm high, dated around the 9th-10th centuries; no. 6023), a Maitreya statue $(25.0 \mathrm{~cm}$ high with the lower half of the body missing, dated around the 8th-9th centuries; no. 6025 c149), and an eight-armed Avalokiteśvara (53.0 $\mathrm{cm}$ high, dated around the 9th-10th centuries; no. 6024). 9) The total height of each of these statues is large in comparison to those found in Java. Comparing the four-armed standing Avalokiteśvara of this study with the figures mentioned above, it becomes obvious that features such as the body height are similar, but there are several differences in the details such as the facial anatomy and the bodily proportions. This suggests that even among the works in South Sumatra, there were different stylistic tendencies according to different geographies. The statue in this study, discovered at the same time as the four-armed Avalokiteśvara (no. 04.0943), differs slightly with respect to facial anatomy and other features, but its simple adornment, facial expressions, the three lines below the neck, the wide shoulders, the bodily proportions and so forth suggests that the statue belongs to the same stylistic group as statue no. 04.093 .

\section{Conclusion}

Features of this statue such as the overall body position curved in an S-shape, the lower body showing less motion compared with the upper body, the thin skirt, and the legs that show movement, can be considered to be Indian influence. The size and facial anatomy suggest that the statue follows the tradition of the Malay statues. Most of the cast metal statues on the island of Java are small with the height measuring around 20.0 $\mathrm{cm}$. Compared with these statues, this statue unearthed in Jambi, South Sumatra, is twice as tall and finely crafted, with differences in form such as the wide shoulders, which depart from the Javanese statues. Thus, similar to statue no. 04.093, this statue (no. 04.094) too most likely belongs to the Malayan Śrivijaya style, different from that in Java. Judging from the fact that the three images discovered in Sumatra are dated around the 9th to 10 th centuries, statue no. 04.094 was probably created around the 
10th century, is no less technologically advanced than the other three images, and belongs to the same lineage as statue no. 04.093 that was excavated together with this statue.

I conducted this survey at the Jambi Museum on March 7 and 8, 2014, and was given permission to publish the photographs.

\section{Notes}

1) See Itō $2015,1333-1340$.

2) See Itō $2007,148$.

3) See Itō 2007, 141-143, 147.

4) In this study, all figures bearing miniature Buddha figures (kebutsu) on the headdress are considered Avalokiteśvara figures.

5) See Itō 2007, 148.

6) Kempers 1959, pl. 43.

7) See Itō $2007,147$.

8) See Shirukurōdo-gaku Kenkyū Sentã 2001.

9) Kempers 1959, pls. 174-176.

\section{Bibliography}

Itō Naoko 伊藤奈保子. 2007. Indoneshia no shūkyō bijutsu: Chūzōzō, hōgu no sekai インドネシアの宗 教美術: 鋳造像・法具の世界. Kyoto: Hōzōkan.

- 2015. "Study of a Four-armed Gilt Bronze Standing Avalokiteśvara Unearthed in Jambi, South Sumatra." IBK 63 (3): 1333-1340.

Kempers, A. J. Bernet. 1959. Ancient Indonesian Art. Amsterdam: C. P. J. van der Peet.

Shirukurōdo-gaku Kenkyū Sentā シルクロード学研究センター, ed. 2001. Kannon bosatsu-zō no seiritsu to tenkai: Henge kannon o chūshin ni Indo kara Nihon made 観音菩薩像の成立と展開: 変化 観音を中心にインドから日本まで. Shirukurōdo-gaku kenkyū シルクロード学研究 11. Nara: Shirukurōdo-gaku Kenkyū Sentā.

(Grant-in-Aid for Scientific Research (C): Art Historical Survey and Study of Śrivijaya, in Sumatra and the Malay Peninsula, Research Project Number: 15K02141)

Key words Śrīijaya, Jambi, South Sumatra 
(286) Study of a Four-armed Gilt Bronze Standing Bodhisattva Unearthed in Jambi, South Sumatra（ITō)
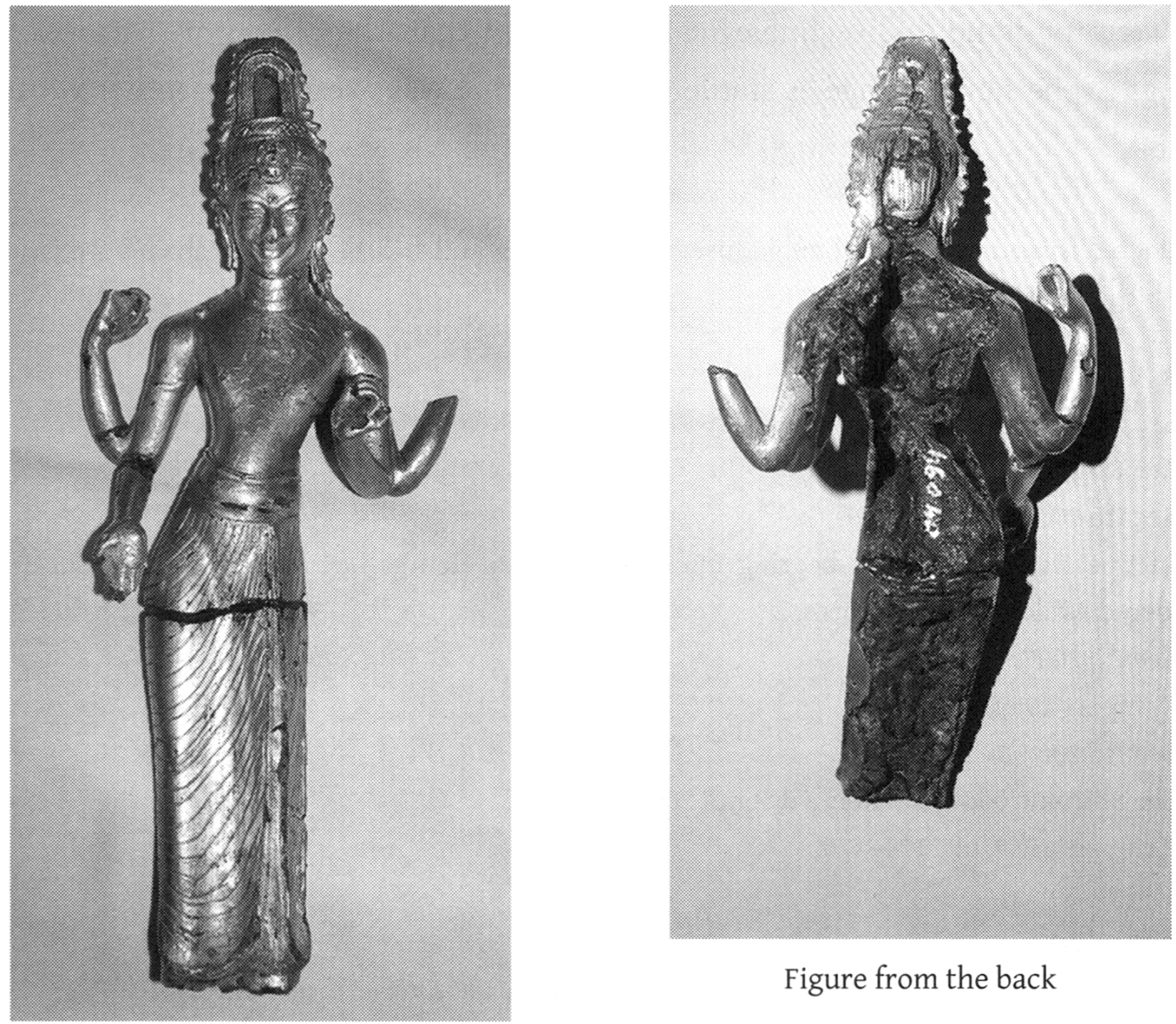

Figure from the back

Figure from the front

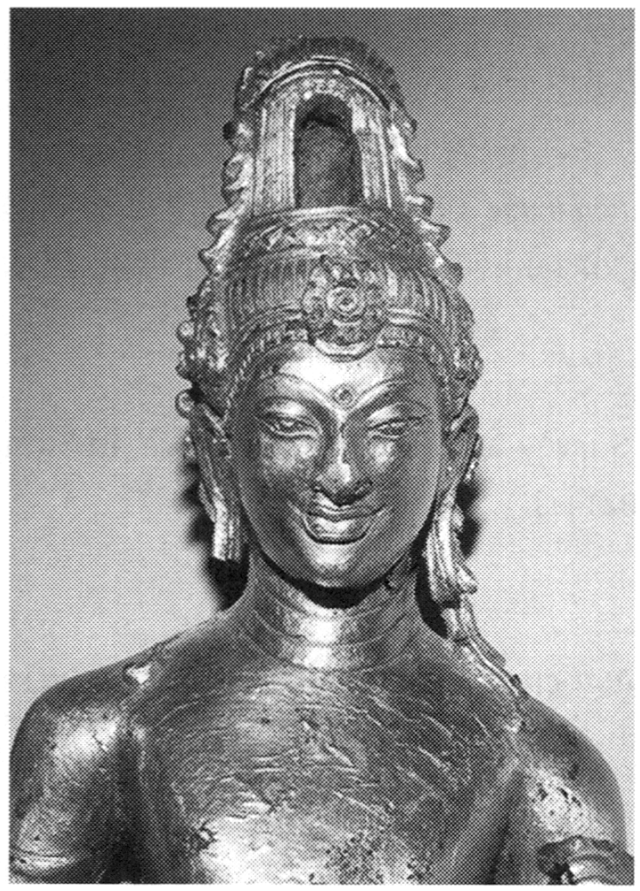

Face (detail)

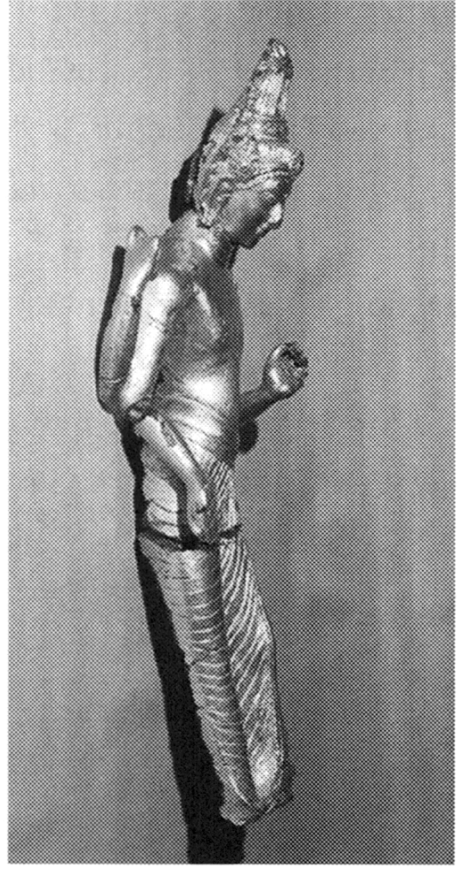

Figure from the side 